\title{
IACOBUS PUBLICIUS'S ARS MEMORATIVA: AN APPROACH TO THE HISTORY OF THE (PRINTED) TEXT*
}

\author{
LUIS MERINO JEREZ
}

\begin{abstract}
Three stages can be distinguished in the history of the printed text of Iacobus Publicius's Ars memorativa. The first one comprises two volumes published in Toulouse and Paris, around 1477. The same stage in the composition of the text is also to be found in a later edition (around 1489). Two versions have been preserved of the second stage of the text: the version that is possibly earlier in time (around 1481) lacks tituli and even omits the author's name. It also contains several engravings, all of them with moving parts, representing the combination of imagines and literae reales. The second version of this second stage was published in Venice in 1482 at the Ratdolt printing press. The Ars memorativa was associated with two rhetorical treatises (Institutiones oratoriae and Ars epistolandi), and the resulting volume was published under the generic title Oratoriae artis epitomata. This version includes a mnemonic alphabet that largely coincides with the one presented in the 1481 version, although now almost all images are fixed. Regarding the text, the main novelty is a profound rearrangement of the contents throughout all the books. The last stage (1485, by Ratdolt) wants to achieve two aims: put the three books on the same level despite having been clearly in favour of the first one before, and homogenize the content of each of the three books. The result is a well-balanced work from a doctrinal point of view and an interesting one from the editorial, which both surely explain much of its success.
\end{abstract}

Keyworsds: Publicius; Ars memorativa; Ratdolt; mnemonic; memoria

Publicius's Ars memorativa is a well-known text nowadays, especially after the study by Mary Carruthers and Henry Bayerle and the English translation by the latter, in the book The Medieval Craft of Memory. ${ }^{1}$ This work constitutes the best starting point for

* This research has been made possible by support from the Spanish Ministry of Science, Innovation and Universities and the European Regional Development Fund. Research Project FFI2017-82101-P: "Text and images from memory II: Rhetoric and Memory arts in the fifteenth and sixteenth centuries".

1 Carruthers, Ziolkowski (2002). The translation of Publicius's text is by Bayerle (2002), which is the English version that I follow here unless otherwise noted. 
those who approach Publicius's text and wish to make new hypotheses on certain aspects that are yet to be clarified, for instance, the history of the text, especially the printed text. Indeed, the Ars memorativa is a text that, after a brief evolution, culminates in the Venice edition of 1485, which establishes the final version, even though it was not the last printed edition. The time and place of composition of Publicius' Ars memorativa is unknown, although it is likely to have happened in the scholarly environment of one of the many universities where this "wandering humanist" is recorded as being enrolled between 1458 and $1470 .^{2}$ Quite possibly, the making of this treatise on memory had to do with the growing interest in this type of literature among university students in central Europe. Thus, it is safe to assume that it may have been a "cover letter" of sorts in his university career. ${ }^{3}$

Many handwritten and printed versions of Ars memorativa are kept at present. Their comparison constitutes an indispensable step to learn a history of that text. So, our main aim here is to compare the printed versions, since, from our point of view, the result of such a comparison will allow us to establish the essential stages of that text which are worth to be pointed out in its evolution up to reach the 1485 Venetian version. In other words, both the printed and handwritten versions reflect an evolution which, as we try to show here, is developed by stages, ones taking place over time while others overlapping each other. The comparison of the printed versions allows establishing the essential goal of a history of the text which is also reflected by the handwritten versions, but these latter will be dealt with on another occasion.

There are many extant manuscripts of this work, known thanks to the rigorous work of Sabine Seelbach and Angelika Kemper. ${ }^{4}$ The twenty-seven manuscripts that have survived are not necessarily older than the printed versions, and they are quite often mere copies of the text in question. Some are of particular interest because of the images they include, such as the well-known copy by Thomas Swalwell, a monk at Durham, which is housed at the British Library (Ms. Add. 28805). ${ }^{5}$ Others, by contrast, are worthy of mention because of the text annotations and the interlineal comments. Such is the case of the obscure anonymous fragment in the prologue of the manuscript at the Biblioteca Nacional (Madrid Ms 9309). The collation of the manuscripts, a task that remains to be completed, will undoubtedly shed light on the history of the text, but for the moment, this study will be confined to analyzing the evolution of the text in the known printed versions.

The catalogues of incunabula record 12 printed editions of Publicius's Ars memorativa, four of which were published as separate works, ${ }^{6}$ three as part of a larger volume

\footnotetext{
On Publicius' biography, see Sottili (1975; 1985); Wójcik (2016: 69-73); Kemper (2018).

Kiss (2008: 108).

4 Heimann-Seelbach (2000: 116-121). More recently, Kemper (2019) has updated the first $27 \mathrm{manu}$ scripts in the introduction to the German edition and study notes of the Ars memorativa.

5 Volkmann (1929: 124-131 and figs. 113-124); Thayer (2016). According to Carruthers, Bayerle (2002: 226), this manuscript is a copy of the second Venice edition by Ratdolt (1485), although in our view, it is actually closer to the first edition (1482), as will be shown in a forthcoming essay.

6 Ars memorativa: GW M36443 [Toulouse: Henric Turner, around 1475-1476]; GW M36442 [Paris: Petrus Caesaris and Johannes Stol, around 1475-1480]; GW M36437 [Cologne: Johann Guldenschaff, around 1481]; GW M36439 [Paris: Antoine Caillout, around 1484-1490].
} 
that included other texts on rhetoric by Publicius, ${ }^{7}$ one together with the poem Regimen sanitatis salernitanum, ${ }^{8}$ and four together with Baldovinus Sabaudiensis's Ars memorie. ${ }^{9}$

It is not possible to determine the exact chronology of the printed editions because of the lack of verifiable data about printers, places, and dates. In addition, the editorial chronology of Ars memorativa does not always match the different stages of the composition of the text, as was also the case of Ars epistolandi. Indeed, some of the later editions reproduce the first version of the text. More specifically, Publicius's Ars epistolandi contains a chapter on the openings of epistles ad Romanum Pontificem. In the first edition by Ratdolt (1482) the argument is illustrated with the name Paulus Secundus. ${ }^{10}$ However, later editions by Ratdolt (Venice, 1485; Augsburg, 1490) ${ }^{11}$ update the name of the Pope to Innocentius Octavus, who ascended to the papacy in August 1484. This reference suggests that Ars epistolandi was composed during the papacy of Paulus Secundus and was later updated on the occasion of the second Venice edition (1485). This allusion is kept in the 1490 edition, when Innocentius Octavus was still the Pope. In this regard, there are two facts that strike the reader. First, that the 1482 edition does not cite the reigning Pope at the time, Sixtus Quartus, and second, that the majority of the editions of Ars epistolan$d i$ published between 1488 and 1502 in printing presses other than Ratdolt's continue to mention Paulus Secundus in the chapter ad Romanum Pontificem. ${ }^{12}$ The same happens in the case of Ars memorativa since, as we shall see, some later editions reproduce earlier stages of composition of the text. Under these circumstances, it seems reasonable to abandon the editorial itinerary and focus on the history of the text itself. In this regard, we will firstly draw our attention to the three stages which must be pointed out in the history of the text. Later on, we will make a note of the changes which had to be added throughout the following stages. In this way, we will note down the changes added around 1482 (second stage: Bod, NY, V82) in relation to the first versions (first stage: $\mathrm{M}, \mathrm{G}, \mathrm{Z}$ ) and to the changes already made in the 1845 Venetian version (third stage: V85, V90) regarding the previous stage.

7 Oratoriae artis epitomata: GW M36431 Venice: Erhard Ratdolt, 1482; Venice: Erhard Ratdolt, 1485; [Augsburg:] Erhard Ratdolt, 1490. Redgrave (1894).

8 Regimen sanitatis salernitanum: GW M36441 Paris: Alexandre Aliate, [after 1500].

9 Liber de arte memorie: GW 03207 [Lyon: Jean du Pré, around 1489]; GW 03208 [around 1495]; GW 03209 Paris: Etienne Jehannot, [1495-1497]; GW 03210 [Lyon: Pierre Mareschal and Barnabé Chaussard, around 1500]. In his list of nine editions, Wójcik (2012: 409-410) includes two that do not contain Ars memorativa: Ars epistulandi orandique modus, Leipzig: Wolfgang Stöckel, [around 1504] (GW M36423); and Institutiones oratoriae et ars epistolandi, Reutlingen: Michael Greyff, [around 1491] (GW M36429). See Carruthers, Bayerle (2002: 226).

10 V82, b3: Divo Paulo secundo, domenici gregis pastoris pietissimo [...] divo Paulo secundo sacrorum antistiti [...] Paulus secundus divino dei nutu [...].

$11 \mathrm{~V} 85$ and V90, [f7v-f8r]: Divo Innocentio octavo, domenici gregis pastoris pietissimo [...] divo Innocentio octavo sacrorum antistiti [...] Innocentius octavus divino dei nutu [...].

12 Ars conficiendi epistolas elegantissime Tulliano more in lucem redacta: GW M36417 1488, Civ.; GW M36419 [1488], B4v; GW M36415 [around 1490], B3; GW M36422 [around 1502], [C2v.]; GW M36423 [around 1502], [C8]. However, a joint edition of Ars oratoria and Ars epistolandi cites Innocentius Octavus: GW M36429 [around 1492], [f5v]. 


\section{The three stages in the history of the printed text}

In light of the contents and the structure of the work itself, three different stages can be identified in the edition of the printed text. The first stage is prior to 1482 and is represented by two volumes sine anno et sine loco, one of them kept in a factitious volume at the Bibliothèque Mazarine of Paris (Inc 618-5) (M) and the other at the Bibliothèque Municipale de Grenoble (I.320[3] Rés.) (G). These are two different editions. The one at the Bibliothèque Mazarine does not have a date, printer, or printing place - although the information provided by the bibliographical catalogues of some authors, such as Carruthers, indicate that it was printed in Toulouse between 1475 and 1476, perhaps at Henric Turner's press. ${ }^{13}$ Similarly, the bibliographical catalogues suggest that the volume kept in Grenoble may have been published in Paris by Petrus Caesaris and Iohannes Stoll between 1475 and $1480 .{ }^{14}$ It must be noted that the Grenoble volume is incomplete, one of the pages has been rearranged, and it is not without errata. Still, the errata are fewer that in the volume at the Bibliothèque Mazarine. ${ }^{15}$ At any rate, the examination of these two printed texts throws in relief that, even though the printers had different sources to work with, both texts follow the same version. ${ }^{16}$ Indeed, both volumes share their incipit (Iacobi publitii in arte memorie prologus feliciter incipit) and explicit (Explicit ars memorativa Iacobi publicii), ${ }^{17}$ but, above all, they arrange the chapters and contents in the same way. Finally, neither of these two volumes include the changes that were made to the text after the Venice edition of 1482.

This first printed version is also the one that reproduces the edition of Publicius's Ars memorativa which was published together with Baldovinus Sabauldiensis's Ars memorie -probably made by Jean du Pré in Lyon around 1489 (Z). ${ }^{18}$ This edition does not match those volumes at the Mazarine and Grenoble libraries exactly, as the text reads differently on some occasions ${ }^{19}$ changes usually improve the text, though not always. At any rate, the most notable aspect in this regard is the insertion of some passages and the inclusion of engravings at the end of the volume. With respect to the inserted passages, it can be observed that two brief examples have been added in the chapter de opposito. ${ }^{20}$ Also, the verses which illustrate literarum figurae reales have been expanded and, in the same place,

${ }_{13}$ Carruthers, Bayerle (2002: 226); Hillard (1989: no. 1702).

14 Maignien (1899: 479).

15 In the Grenoble volume, f. [12] erroneously follows f. [11], which itself should actually be f. [12]. Also, f. [14] is missing. It should contain the end of the chapter de effectu rerum; the chapters de suis cuisque rei instrumentis, de partibus humani corporis, de opposito, de accidenti et proprio, de causa, de resolutione, de figuris; and the beginning of de insigniis personarum.

16 This explains some minor variants (however significant) between both volumes. So, for example, we have ridiculum $($ Mazarine $=\mathrm{M}) /$ ridiculosum $($ Grenoble $=\mathrm{G})$; diversitate humana $(\mathrm{M}) /$ diversitate hac $(\mathrm{G})$; reservanda $(\mathrm{M})$ / revellanda $(\mathrm{G})$; opus $(\mathrm{M})$ / opis $(\mathrm{G})$; notabulis $(\mathrm{M})$ / vocabulis $(\mathrm{G})$. Occasionally, we find terms in one version that do not occur in the other, such as elingues $(\mathrm{G})$, inde $(\mathrm{G})$; abolitione $(\mathrm{G}) ; \operatorname{iam}(\mathrm{G}) ; \operatorname{sic}(\mathrm{G})$; esse $(\mathrm{M})$.

17 The Grenoble volume has Publicii both in the incipit and in the explicit.

18 GW 03207. Out of the four extant copies of this edition, only one still has the engravings; namely, that at the Biblioteca Universitaria de la Universidad de Zaragoza (I 163.4) (Z).

19 By way of illustration, the title is amended of the chapters de corroboratione memorie and que conferunt et que obsunt memorie (de corroboratione materie and que conferunt et que obsunt materiae in $\mathrm{M}$ and $\mathrm{G})$. Cf. Z, [a7v-a8r].

20 Ut Nero, misericors; Hector, timidus (Z, biiiv). 
an explanation has been introduced on the figurative understanding of the grammatical cases by association with parts of the human body. ${ }^{21}$ Finally, there is also a new lengthy paragraph on the dictio spiritualis at the end of the chapter de sententia. ${ }^{22}$ The absence of any further references to these insertions in the rest of editions seems to indicate that they were not Publicius's. ${ }^{23}$ However, the final disquisition on dictio is not completely alien to the text of Ars memorativa, since dictio is one of the six elements displayed in the engraving of the tree of memory that closes the Venice edition of $1485 .^{24}$

These engravings also match the notions Publicius formulated, especially in the second book. ${ }^{25}$ The volume kept at the Universidad de Zaragoza (Z) contains four folds with illustrations at the end of the text. The first of them depicts a half-naked man in a loincloth and seventeen figures of letters (Fig. 1). ${ }^{26}$ The next fold has twelve figures of letters (Fig. 2). The third one, four more figures of letters plus a series of Greek and Hebrew letters and a square grid (Fig. 3). ${ }^{27}$ The last fold is deteriorated and possibly incomplete, as indicated by the fact that the Arbor artis memorie only lists three elements in its trunk (tempus, genus, locus) as opposed to the six elements in the Venice edition of 1485 (tempus, genus, locus, sententia, persona, dictio) (Fig. 4). ${ }^{28}$

21 Omni re carta O sit tibi rotunda. Omnis homo naturaliter se habens, nominativi casus; genubus flexis, genitivi casus; sedendo, dativi; versa facie in celum, accusativi; prostratus in terra, vocativi casus; caput contra terram et pedes contra celum versus, ablativi casus significabit $(\mathrm{Z}, \mathrm{b} 2 \mathrm{r})$.

22 Dictio spiritualis est duplex: significativa et non significativa. Spiritualis significativa est duplex: scilicet propria et impropria (...) dictionem compositam res composite, dictionem simplicem res simplex; tota totum, sic vel sic, media medium, tertia tertium, quarta quartum et sic consequenter significabit (Z, b5v).

23 It should also be noted that Romberch, the main champion of Publicius, records a different explanation about the mnemonics for the grammatical cases; and that the argument on dictio spiritualis appears right after the statement that concludes Ars memorativa.

24 To this day, this is the only edition that has a complete arbor artis memoriae. The rest either have it missing (M, G, NY/Bod) or incomplete (Z). On the other hand, it turns out necessary to consider whether the image of the tree of memory does not recall the Pseudo-Lullian art of memory: Yates (1966: 173-198); Rossi (2000: 76-77).

25 The first explicit reference to the engravings occurs at the end of the first book, in the chapter de locis commenticiis, where Publicius recommends that places ne fulgida splendescant vel obscura opacitate oblecta prorsus lactitent, sed distincta et clara, ut sequenti figura evidens est. The only edition that heeds this warning is the second edition by Ratdolt, which includes an engraving of the cosmos where three continents are mentioned (Asia, Europe, Africa), the four elements are represented (earth, water, air, fire) and we can see the symbols of the planets and the three highest layers of the heavens: celum nonum, celum cristallinum, and paradisus (V85, [g7r]).

26 The engravings of the mnemonic alphabet in this edition $(Z)$ are of lesser quality than those in the Ratdolt editions. On the whole, however, the objects and shapes depicted in them are roughly the same. The shape of some letters, such as $\mathrm{M}$, bear a stronger resemblance to the letters in the edition attributed to Guldenschaff (NY/Bod). The fact that some of the letters are not represented in it and also that there is no female figure to go with the male, suggests that some folds may have been lost.

27 The engraving that displays a square is used to describe the tenets of the second book, where we learn about the methods to make mnemonic words by the combination of letters that are placed on the edges of the square: Si literarum loca et dispositionem noscere volemus, vocales namque extrinsecis centro collocabimus, relique vero litere vacua loca ordine sortiantur, quod facile exitus dictionum complecti et claudere possimus (M, [153v]; G, [8v-9r]). The Zaragoza volume (Z, b1v) has varia (instead of vacua), which is perhaps no mere coincidence because the drawing has no letters and also lacks the necessary mechanism to combine vowels and consonants, as we shall see in the Ratdolt editions (V82, [d3v] and V85, [h8r]). Bayerle (2002: 249 n. 51 and 252-254) explains how this complex mechanism works through its reception in Romberch's Congestorium. Others, by contrast, such as Conrad Celtis, outspokenly criticized this method, as reported by Kiss (2008: 108-109).

28 Although small changes may be noted, on the whole, the distribution of the elements in the extant parts of the engraving match the Ratdolt edition (V85). The first Ratdolt edition (V82) does not have 


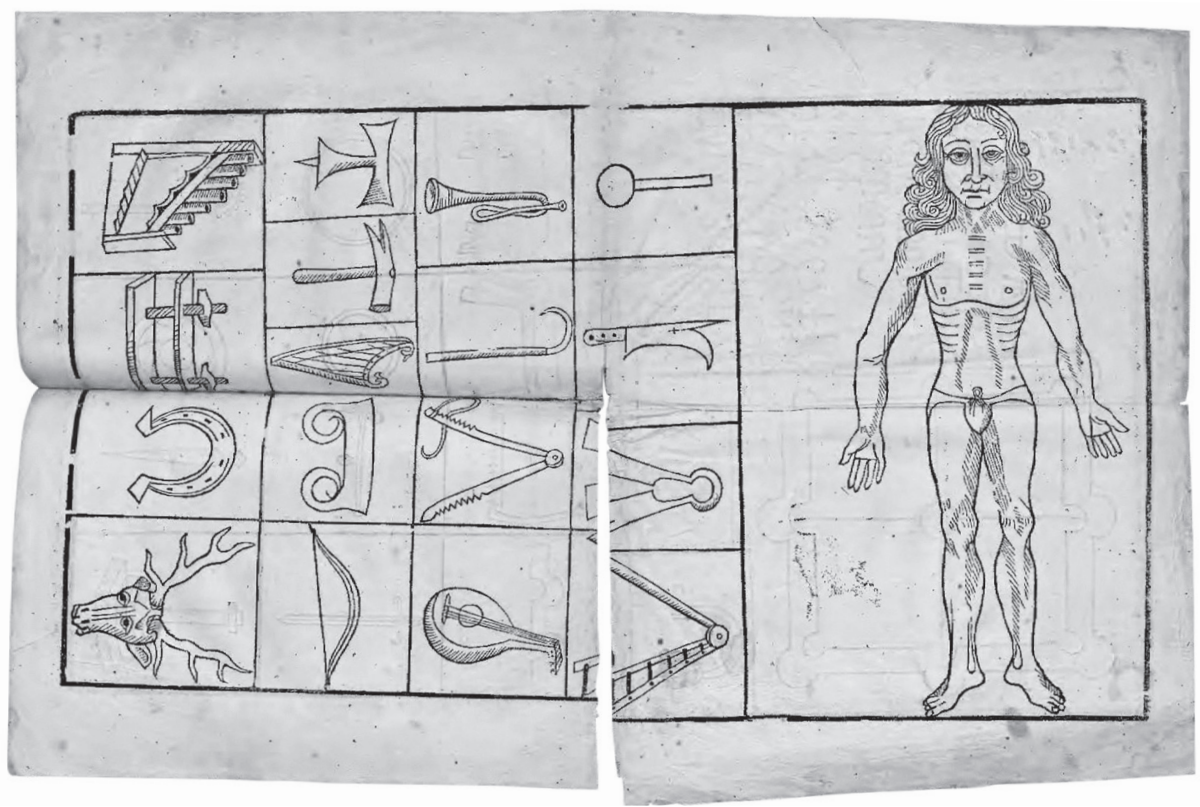

Fig. 1: Naked man and mnemonic alphabet (letters $\mathrm{A}^{3}, \mathrm{~B}^{2}, \mathrm{C}^{1}, \mathrm{D}^{2}, \mathrm{~F}^{1}, \mathrm{P}^{2}, \mathrm{~S}^{1}, \mathrm{~T}^{2}, \mathrm{~V}^{3}$ ). Iacobus Publicius, Ars memorativa, [Lyon: Jean du Pré, around 1489]. Biblioteca Universitaria de Zaragoza, Fondo Antiguo I 163-4.

In all, despite the fact that the date of this volume $(\mathrm{Z})$ is later than Ratdolt's Venice editions (V82 and V85), the text itself coincides for the most part with the volumes kept at the Mazarine and Grenoble libraries. The engravings in this version $(Z)$, although incomplete in the only volume that still has them, follow the notions described in the book and they are likely to have been very similar, if not identical, to those that were printed in the editions before Ratdolt's ( $M$ and $G$ ).

The second stage of composition of this work also spans two editions. The first and best known edition is that printed in 1482 by the German printer Erhardus Ratdolt in his Venetian workshop. This edition consists of a compilation of works by Publicius, collectively entitled Oratoriae artis epitomata. This volume comprises Oratoriae institutiones, some Scribendi breves rationes, and finally Ars memorativa. Like in the case of the cover and colophon to the volume, the incipit of Ars memorativa describes Publicius as Florentinus. ${ }^{29}$ Plenty of copies of this edition are extant in many libraries. ${ }^{30}$ This, together with the typography of the text and the beauty of the engravings, made this the editio princeps for many - i.e., they forgot about the aforementioned volumes in Paris and Grenoble. ${ }^{31}$

the arbor artis memoriae, although it is alluded to, as well as in all the other editions consulted: $D e$ quibus tabulam dupliciter depictam in medium afferam, ut facilior exitus huic operi detur (M, [163v]; $\mathrm{G},[14 \mathrm{r}] ; \mathrm{Z},[\mathrm{b} 5 \mathrm{v}])$.

29 V82, c1: Iacobi Publicii Florentini ars memorie feliciter incipit et primo prefatio.

30 GW M36431: 106 copies.

31 Carruthers, Bayerle (2002: 226) acknowledged the existence of an Ars memorativa that "was printed first as a separate work in Toulouse in 1475/6, perhaps by the printer Henricus Turner." 


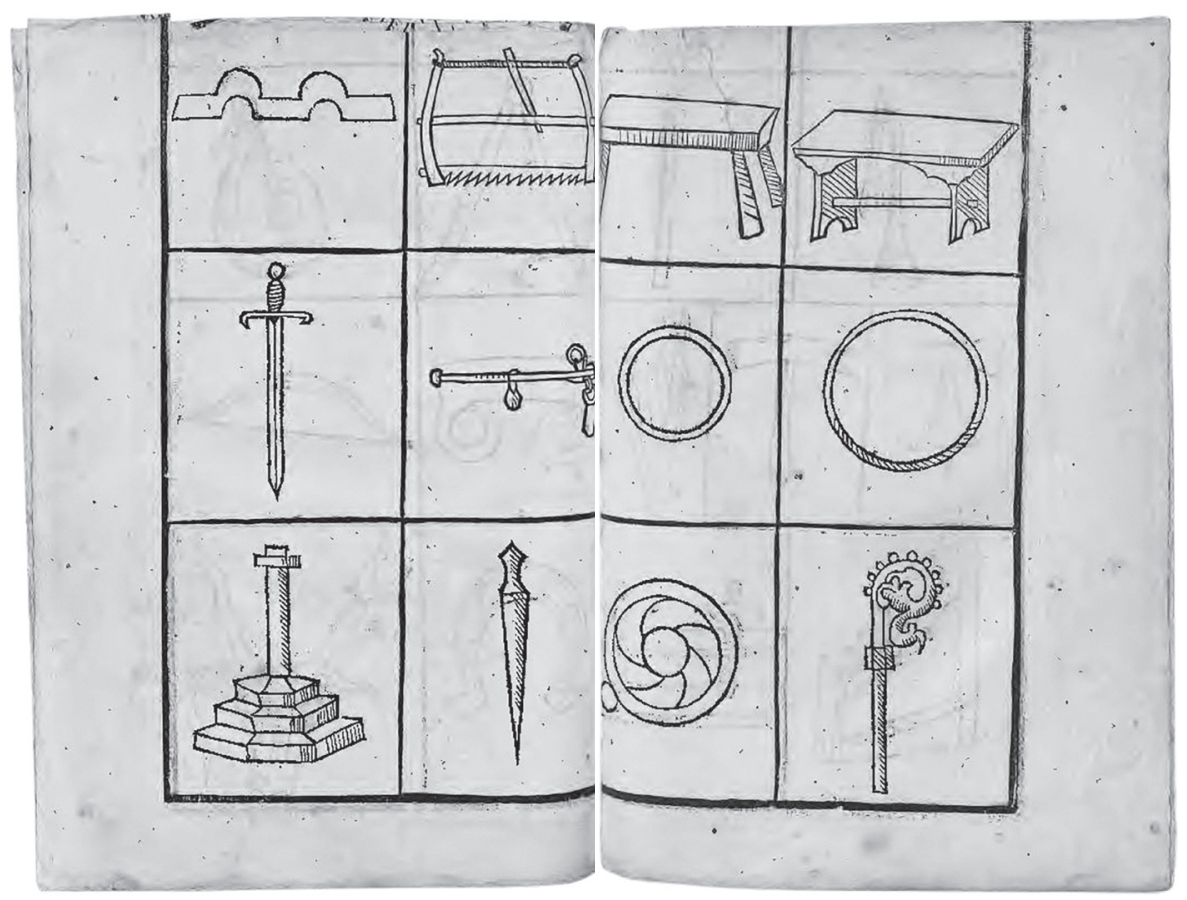

Fig. 2: Mnemonic alphabet (letters $\mathrm{E}^{2}, \mathrm{I}^{3}, \mathrm{~L}^{1}, \mathrm{~N}^{2}, \mathrm{O}^{3}, \mathrm{P}^{1}$ ). Iacobus Publicius, Ars memorativa, [Lyon: Jean du Pré, around 1489]. Biblioteca Universitaria de Zaragoza, Fondo Antiguo I 163-4.

Another version has also been neglected, although it is likely to be earlier than the Venice edition of 1482. Several copies of this version are kept in libraries including The New York Public Library (NY), ${ }^{32}$ the Bodleian Library at Oxford (Bod) ${ }^{33}$ and the Staatsbibliothek zu Berlin (SB). ${ }^{34}$ By comparing these three copies, we can say that all of them belong to the same edition, as corroborated by how closely they match, even in typographical errors. ${ }^{35}$ These three copies present Ars memorativa as an independent, apocryphal work. The incipit does not mention the name of the author. It does not cite a place, a year, or a printer, but the typographical features suggest that these three copies belong to the edition printed in Cologne by Johann Guldenschaff circa $1481 .{ }^{36}$ This edition, likely to have been

32 Available at SASB, Rare Book Collection Rm $328\left({ }^{\star} \mathrm{KB} 1483\right)$.

33 Available at Bod-inc., P-535.

34 Available at $8^{\circ}$ Inc 899.7. This issue lacks the engravings.

35 A few differences of little consequence may be noted here: the volume at the New York Public Library does not have initials and includes the engravings at the end; the issue at the Bodleian Library has initials in black ink and the engravings precede the text; finally, the issue at the Staatsbibliothek zu Berlin has neither initials nor the engravings. The engravings in the New York and Oxford copies are identical, although they are incomplete and do not follow the same order.

36 Denis (1789: 646). Publicius arrived in Cologne in 1468 and stayed there until 1469. However, if we consider that the incipit does not mention the name of the author, one may hypothesize that the edition of the text occurred after his departure, perhaps between 1480-1481 as suggested in GW M36437. We believe this is the same edition that Carruthers, Bayerle (2002: 230) attribute to Antoine Caillaut, who allegedly published it in Paris between 1484 and 1490. 


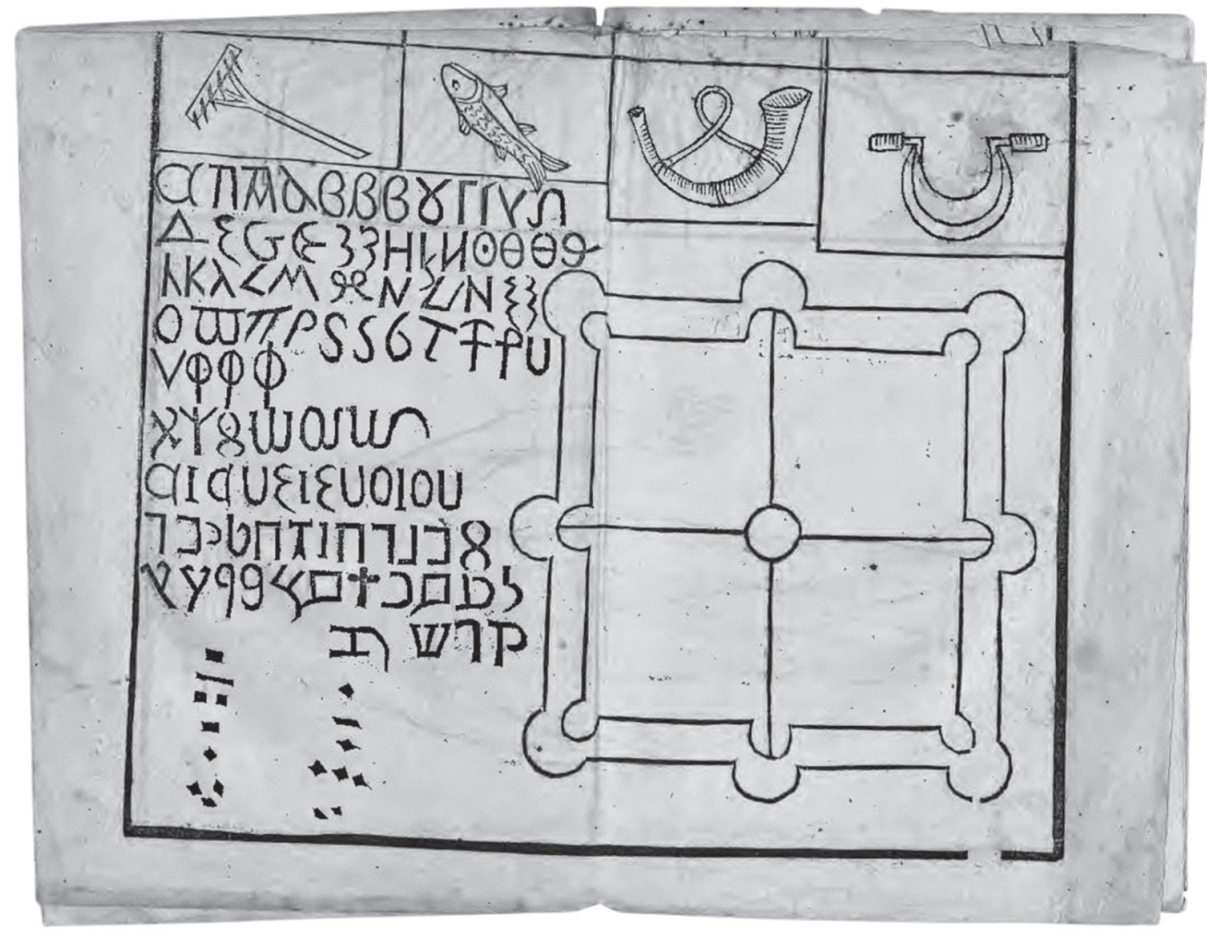

Fig. 3: Mnemonic alphabet (letters $\mathrm{I}^{2}, \mathrm{C}^{2}$ ), Greek and Hebrew alphabets, mnemonic square. Iacobus Publicius, Ars memorativa, [Lyon: Jean du Pré, around 1489]. Biblioteca Universitaria de Zaragoza, Fondo Antiguo I 163-4.

published by Guldenschaff, was not divided into capituli and it also featured engravings that differed from those in the Venice edition of 1482. However, the text of Ratdolt's first edition (V82) matches that of the edition attributed to Guldenschaff (NY/Bod). Thus, it is safe to say that both editions represent the same stage in the composition of the text.

The third stage in the composition of the printed text is represented by the Venice edition of 1485. This version has the largest number of extant copies, so it is safe to assume that it was an editorial success. ${ }^{37}$ In addition, this is the final version of the text and the version that had the greatest influence on later authors - whether because it was carefully crafted or because it is the edition with the most engravings. ${ }^{38}$ This edition of Publicius's Ars memorativa is, incidentally, the best known at present and represents the reference edition for the study of this work - for want of a modern critical edition that, of necessity, must eventually take into account the rich manuscript tradition ${ }^{39}$ and the later reproductions of the text in joint editions with other texts and authors.

37 GW M36435: 116 copies. See Wójcik (2012).

38 After leaving Venice, Erhard Ratdolt settled in Augsburg, where he again published the Oratoriae artis epitomata in 1490 (GW M36428). This edition reproduces the Venice edition of 1485 without any changes in the text or the engravings.

39 Heimann-Seelbach (2000: 116-121). 


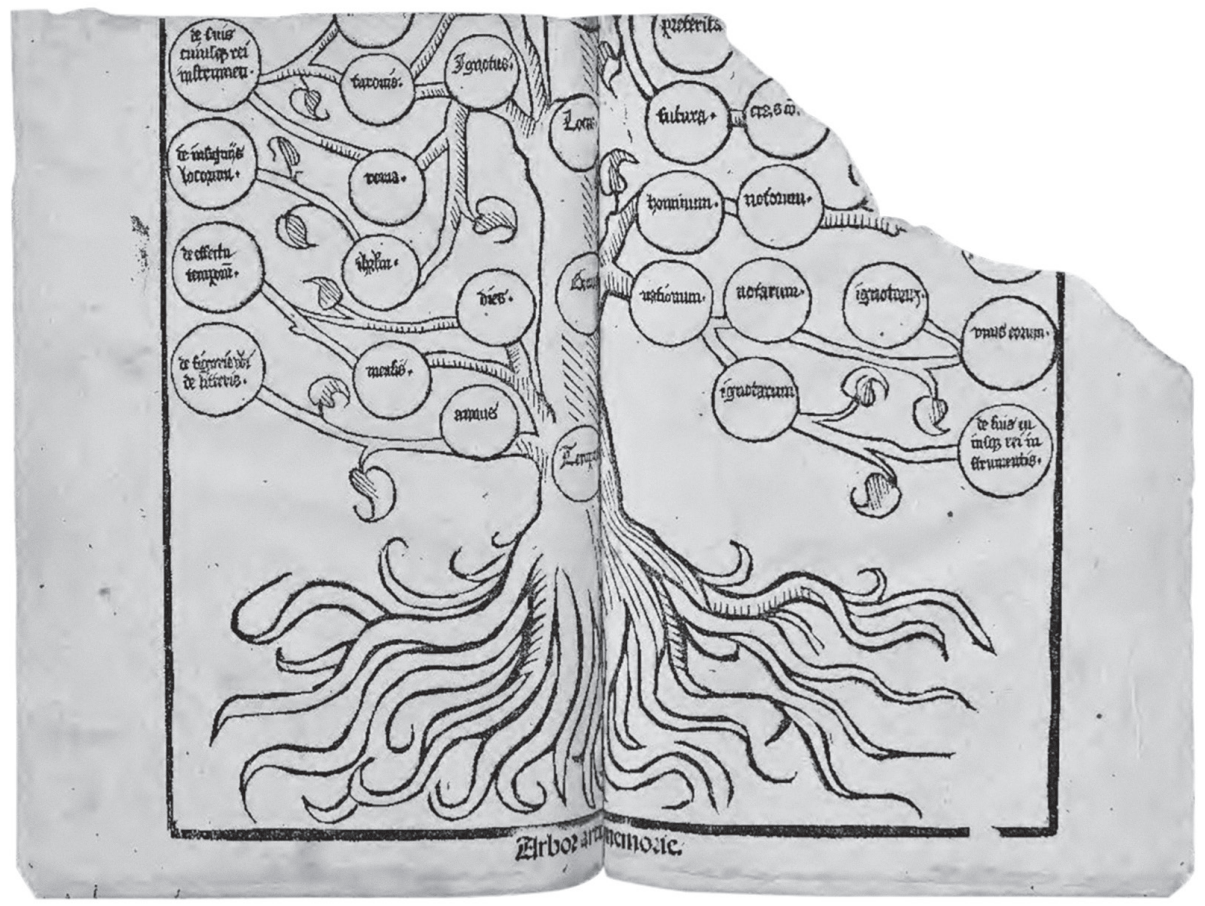

Fig. 4: Arbor artis memorie. Iacobus Publicius, Ars memorativa, [Lyon: Jean du Pré, around 1489]. Biblioteca Universitaria de Zaragoza, Fondo Antiguo I 163-4.

Once these three stages have been established, we shall move on to analyse the changes in the progressive fixation of the text of Ars memorativa.

\section{The printed text of Ars memorativa: from the first to the second stage}

The first stage of the printed edition of Ars memorativa corresponds to two copies printed before 1482 in different places and on different dates ( $M$ and $G$ ), as well as to a later version $(Z)$, whose text is for the most part identical to that of the first stage. It has already been mentioned that the engravings in this later edition $(Z)$ were probably quite similar to those in the first two editions, which are unfortunately lost. However, the most relevant fact about this first printed edition ( $M, G$ and $Z$ ) is that it foreshadows the structure of the text that would later be expanded in the 1482 edition and modified in the 1485 edition.

The work begins with a prologus containing a general disquisition about memory. This is followed by Primus libellus, covering two broad topics: places and medicinal advice for memory. Liber secundus is brief. It is restricted to litterarum ratio; i.e., a method to make mnemonic words by dint of a combination mechanism of vowels and consonants that are 
laid out on a quadrangular grid. This method is referred to as quadrati norma ${ }^{40}$ in the first book. Tertius liber is devoted to imagines and, according to Publicius's words, it consists of four parts. The first part is not singled out as an independent section itself, but it is safe to assume that it comprises the preliminary discussion on imago. The second part deals with the twelve types of signa, which Publicius discusses with varying degrees of detail, each in a separate chapter with their own individual title. The third part, entitled de figuris, delves into rerum realium formae. The fourth and final part analyzes three types of insignia (personarum, locorum, rerum). ${ }^{41}$ The work does not end here, however, for there is a chapter entitled De sententia before the explicit, where Publicius comments on how to memorize sententiae, syllogisms, and arguments. As regards the sententiae, he recommends taking into account the following: genus, locus, tempus, persona and sententia.

In the 1482 edition we find that the structure of the text is identical, and the same occurs with the arrangement of the contents within each of the books and the main sections.

\begin{tabular}{|c|c|}
\hline Prologus & Prefatio \\
\hline Primus libellus & {$[\text { Primus libellus] }]^{42}$} \\
\hline Liber secundus & Liber secundus \\
\hline Tertius liber de imaginibus & Liber tertius et ultimus \\
\hline De sententia & [De sententiis] ${ }^{43}$ \\
\hline$(M, G, Z)$ & $(V 82)$ \\
\hline
\end{tabular}

However, some differences of varying significance must be noted between both stages. The most obvious difference is the absence of engravings in the first editions ( $M$ and $G$ ). Although, as already pointed out, this should not be taken as an important difference, especially if one takes into consideration that the text of these first editions makes reference to figures that may have been lost over time. ${ }^{44}$ These references are the same as in

40 In the chapter De multitudine locorum (first book), readers are invited to apply quadrati norma - that is going to be discussed in the second book - to other places: Que, qui sine labore multiplicari voluerit, quadrati normam, de quo secundo volumine agendum est, sequitur (M, [145v]; G, [4v]; Z, [a7r]; NY, [5r]). This advice disappears from V85.

41 Superest ut de quarta huius extremi voluminis parte dicamus (M, [161r]; G, [11v]; Z, [b4v]; NY, [b5r]). This reference changes in V85, H2r: Superest ut de quarta huius secundi voluminis iam parte dicamus.

42 The heading of the first book disappeared.

43 The heading of the capitulus is missing, but the text remains.

44 As previously noted, M and G lack images. But in this regard it should be taken into account that $M$ and $\mathrm{G}$ are the unique exemplars of these versions to have survived. $\mathrm{G}$ is mutilus and $\mathrm{M}$ is included in a factitious volume. Furthermore, some images are referred to in $\mathrm{M}$ and $\mathrm{G}$ at the end of the first book: Si distincto ordine sedium ratione excogitata erunt, ne fulgida splendescant vel obscura opacitate oblecta prorsus lactitent, sed distincta et clara, ut sequenti figura evidens est, locorum multitudinem apertam nobis prebeant (M, [152v]; G, [8r]); at the beginning of the second book: Est autem compositio loci et imaginis vel utrorum [utros horum $\mathrm{M}$; utro horum $\mathrm{G}$ ] vis [ius $\mathrm{M}$ ], coniugatio ut hac prima et secunda figura demonstrabitur, qua locorum et elementorum dispositione vocabula distincte variare poterimus (M, [153r]; G, [8v]); and at the end of the first book: De quibus tabulam dupliciter depictam in medium afferam, ut facilior exitus huic operi detur (M, [163v]; G, [14r]). In short, although both copies lack images, the hypothesis that $M$ and $G$ originally included some figures inserted in the middle or at the end of the text should not be ruled out. In any case, $M$ and $G$ reproduce one or more manuscripts that probably included images similar to those that can be seen in $\mathrm{Z}$. 
NY and V82. It is even possible that the figures that were allegedly lost would be roughly the same as the ones in the edition $\mathrm{Z}$ which, despite its later date (1489?), reproduces the text of $\mathrm{M}$ and $\mathrm{G}$ with little variation. Another minor difference has to do with the wording of the incipit. The first editions ( $M$ and $\mathrm{G}$ ) do not have the cognomen Florentinus, and prefatio is referred to as prologus. In addition, Ratdolt's edition omits the capituli in the third book, although it has those of the first book. ${ }^{45}$

Other differences affect the text itself, in which some small changes are introduced, such as the deletion or addition of isolated words or the amendment of erroneous readings. ${ }^{46}$ Of greater importance is the deletion of some brief passages, as in the case of the chapter de insigniis personarum, where we find the signs identifying different dignities, the evangelists, etc. The reference to colus ("spinning wheel") and to catella ("chain") as the signs for women and prostitutes, respectively, disappears from the text for good in the editions of the second stage. ${ }^{47}$ The most significant change in the text is to be found in the second book, containing the procedure to create different mnemonic words by means of the combination of loci and elementa. As a result, the 1482 edition provides an explanation of the mnemotechnic mechanism more easily understandable for the reader. The 1482 Venetian version improves even more the explanation of the system adding some small but significant changes in the text.

The insertion of new contents is equally worthy of note. Thus, for example, to the discussion de figuris in the third book a new paragraph is added that, following the Rhetorica ad Herennium, stresses the importance of using striking images. ${ }^{48}$ But the most noticeable changes occur at the beginning of Ars memorativa. First, in the prologue, in which a new chapter, entitled divisio memoriae, was incorporated in 1482. Second, at the beginning of the first book, where we find a definition of the concept of ordo and a disqui-

45 In most cases the wording of the headings is changed. Thus, the nominative is used instead of $d e$ with ablative: De preceptione / locorum preceptio; de qualitate locorum / locorum qualitas; de multitudine locorum / numerus locorum, etc.

46 See, for example, in the third book, the discussion de effictio: in cano iam mento mundum nasum tergentem $(\mathrm{M},[154 \mathrm{v}])$ / in cano iam mento iam mundum nasum tergentem $(\mathrm{G},[9 \mathrm{v}]$ / in cano mento iam mucidum nasum tergentem (V82, d1v). A clearly erroneous reading in the first printed versions can be seen in the chapter de insigniis locorum: Sic candia et chura, florentia purpuram, valentia risum mittens suo proprio bono denotabitur (M, [162r]; G, [13r]). This is later amended in the versions of the second stage: Sic caudia azathura [...]) (NY, [14r]); Sic caudia zagarum [...] (V82, [d7r]). And also in the final version: Sic candia zugarum [...] (V85, H2). The reference to the city of Valencia in this section is quite significant. Additional external references, such as that to the controversy with Valencian humanist Iohannes Serra, may lead us to believe that Publicius was born there or that "la carriera di professore del Publicio si inaugura a Valenza”, as suggested by Francisco Rico (Sottili 1985: 7-9). Finally, let us add that Leporeus omits the reference to Valencia when he takes this passage over to his Ars memorativa (Morcillo Romero 2015: 126-127).

47 Plato secum peditem trahit Aristotelem; colus mulierum; catella meretricum (M, [161v]; G, [13r]; Z, $[\mathrm{b} 4 \mathrm{v}])$. Missing in NY, [13v]; V82, [d4v]; V85, H2r. There is another example, in the chapter de partibus humani corporis of the second book, where the reference to animals and things is omitted: Item de animalibus et aliis rebus intellige (M, [159r]). Missing in Z, NY, V82 and V85.

48 Magna quippe incredibilia, invisa, nova, rara, inaudita, flebilia, egregia, turpia, singularia ac pervenusta menti et memoriae nostrae ac recordationi plurimum conferunt (NY, [b1v-b2r]; V82, d4r). Here, Publicius follows the advice in the Rhet. Her. III, 36 quite closely: usitatae res facile e memoria elabantur, insignes et novae diutius manent in animo. [...] Docet ergo se natura vulgari et usitata re non exsuscitari, novitate et insigni quodam negotio commoveri. Leporeus reproduces Publicius's text verbatim (Morcillo Romero 2015: 120). 
sition on its application for the sorting of places. ${ }^{49}$ This chapter is substantially enlarged and it looks practically like a new chapter, although one cannot discard the hypothesis that the first versions of the text would follow an incomplete manuscript version, at least in this chapter of Ars memorativa. The analysis of the summary that closes the first book seems to reinforce this notion.

Indeed, at the end of the first book Publicius summarizes the main sections covered thus far. ${ }^{50}$ As regards the text of Ars memorativa, this summary presents some significant changes in the titles of the capituli. ${ }^{51}$ It is particularly striking that the summary would include a reference to de lege, since locorum lex does not appear in these first versions of the text $(M, G, Z)$ - although it is found in the two versions of the second stage (NY, V82). Consequently, the summary that closes this book now reproduces the number of chapters and their tituli52 more faithfully, although it would undergo some reworking in the following edition. ${ }^{53}$ If the principles of de locorum lege are an addition ex novo to the second stage of the text, it does not explain why it is mentioned in the closing summary of the first book. ${ }^{54}$ Therefore, it can be assumed that in these first versions of the printed text $(\mathrm{M}, \mathrm{G}, \mathrm{Z})$ perhaps an incomplete source manuscript may have been followed. And what is more, there is reasonable suspicion that the mistake could have occurred because the principles de lege, as seen in later versions, are nothing but a list of the remaining chapters similar to the one found at the end of the first book. In any case, this is just one of the many mysteries of Publicius' text, whose possible solution may follow from an exhaustive study of the manuscript tradition.

\section{The printed text of Ars memorativa: from the second stage to the third}

The second Venice edition by Ratdolt (1485) constitutes the third and the last stage of the history of the printed text because, as noted earlier, the version published by Ratdolt in 1490 is but a reprint. The most obvious change is the insertion of new images, whose

49 The same changes can be observed in the edition attributed to Guldenschaff, following our own perusal of the two volumes consulted (NY/Bod).

50 Ceterum, quoniam de ordine, lege, praeceptione, qualitate, inventione, dissimilitudine, numero, locorum impressione, memorie corroboratione, exercitatione, ingenio conferentium et commentitis locis, cognitione in (sic) mentis dicentes, satis huius primi libelli magnitudine crevit, commodius reliquis de rebus in sequenti volumine dicendum censuimus $(\mathrm{M},[152 \mathrm{v}])$. The list of items is slightly different in the three editions of the first stage of composition: G, [8v] adds abolitione and corrects vi menti; likewise, Z, b1v includes abolitione and changes the word order in vi mentis cognitione.

51 For example: $M$ and $\mathrm{G}$ replace numero with multitudine (M, [145r]; G, [3v]); memorie with materie (memorie / materie corroboratione) (M, [146r]; G, [4r]); uses ambolitione instead of abolitione (M, $[146 \mathrm{v}] ; \mathrm{G},[4 \mathrm{v}])$. The chapter de notatione (M, [147r]; G, [4v]; Z, [A7v]) is not mentioned in the summary (M, [152v]; G, [8v]; Z, b1v).

52 Ceterum quoniam de ordine, lege, preceptione, qualitate, inventione, dissimilitudine, numero, locorum impressione, memorie corroboratione, abolitione, exercitatione, ingenio conferentium, et comenticiorum locorum cognitione dicentes [...] (NY, [b1r], omits cognitione; V82, [c4v]).

53 Ceterum quoniam de ordine, lege, preceptione, inventione, qualitate, dissimilitudine, notatione, impressione locorum, multitudine, et comenticiorum locorum cognitione dicentes [...] (V85, G4v).

54 Locorum lex preceptione, qualitate, inventione, dissimilitudine, numero, impressione, memorie corroboratione, imaginum abolitione, notatione, exercitatione ac ingenio conferentium et vi mentis cognitione commenticiisque locis plene perfecteque constat (V82, c3r). 
presence is justified, according to Carruthers and Bayerle, because the printer wanted the work to be more appealing. ${ }^{55}$

Engravings are mentioned from the earliest editions of the text. From the extant copies ( $M$ and $G$ ), if they were ever printed during this first stage, they have been lost, however. If they were indeed printed, those engravings, as mentioned before, must have been quite similar to those in the $\mathrm{Z}$ edition that corresponds to the first stage of the text despite its late publication date. Whatever the case, the first printed engravings that have survived are to be found in the edition attributed to Guldenschaff (Cologne, c. 1481). The engravings in at least two copies (NY and Bod) allow us to reconstruct the whole set of figures of this version of Ars memorativa. They consist, firstly, of two square checkerboards or "grid diagrams" with a moving figure at the center (Fig. $\mathbf{5}$ and $\mathbf{6}$ ), perhaps the printer's reinterpretation of quadrati norma - announced in the chapter de multitudine locorum of the first book and briefly discussed in the second book. ${ }^{56}$ These are followed by 48 figures of letters "printed on small circular pieces of paper attached to the page by a string so that they can rotate". ${ }^{57}$ The majority of letters represented here coincide with those of the 1482 Venice edition (Fig. 7 and 8). Although there are fewer letters in Ratdolt's edition (V82), new figures have been incorporated. More specifically, six figures of letters (a G, an M, a P, two Vs, and an X) and two additional images that are also inserted in circles, although they are not letters: a vessel at sea and a landscape. In addition, Ratdolt's edition also includes other new images that were already glossed by Carruthers and Bayerle: a brief list of Greek letters, ${ }^{58}$ a "grid diagram" with 25 figures of animals, ${ }^{59}$ a mechanism to create words by combining vowels and consonants, ${ }^{60}$ and a chessboard with the pieces on it. ${ }^{61}$ Apart from the greater number of engravings, it is particularly significant that only one engraving has moving parts in all of Ratdolt's editions, whereas all of the engravings in the edition attributed to Guldenschaff do have moving parts.

55 Carruthers, Bayerle (2002: 229).

56 See supra n. 45.

57 Description by Carruthers, Bayerle (2002: 230), who nevertheless attributed this edition to Antoine Caillout [Paris: between 1484 and 1490]. According to them, "Diagrams with moving parts, made by cutting out pieces of parchment and fastening them to a page, were a commonplace feature in medieval manuscripts, but this is one of the earliest examples in a printed book."

58 The use of Greek (and Hebrew) letters is alluded to in the earliest printed versions: He autem ebree grece reales inanimatae et animatae erunt (M, [152v]; G, [8v]; Z, biv); Diversarum quoque nationum et gentium littere veluti nove nobis et ignote figure cum plurimum mentem in recordationem excitant, grecas hic literas sic subicere consilium fuit, ut diversarum figurarum ratione mentem facilius levare possimus (M, [153r]; G, [9r]; Z, b2r; NY, [biv]; V82, [c7r]).

59 This "grid diagram" was inserted at the end of the work, but it is specifically connected to the advice in the chapter numerus locorum, where we learn how to increase the number of loci memoriae with the help of animal figures: Centum etiam conficta animalia litterarum et alphabeti ordine exquiret ac unicuique figure quinque maxima diformia animalia accomodabit, vel res aliquas animalibus commiscere poterit ut diversitate hac firmius memorie impressa inhereant. In quibus pro eorum magnitudine plurimas ac diversas imaginum sedes pro sententia nostra statuere poterimus (V82, c4r). It should be noted that the series of figures follows, for the most part, the alphabetical order of the Latin names of the animals. In addition, each animal is represented inside a specific architectural design.

60 Bayerle (2002: 249 n. 51 and 252-254) explains this complex mechanism following on Congestorium artificiosae memoriae, by Iohannes Romberch.

61 Although it can be assumed that the chessboard with the pieces on it may work as a locus memoriae, there is no explicit reference to it in the text of Publicius's Ars memorativa. This would indicate that this engraving was inserted by Ratdolt. 

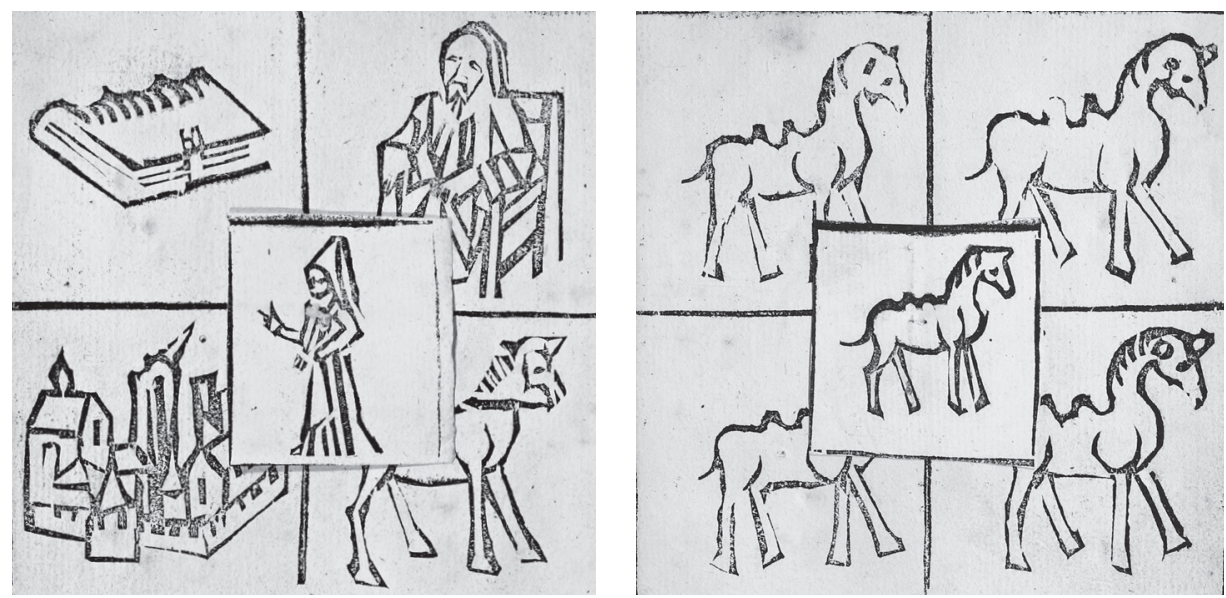

Fig. 5 and 6: Mnemonic grid. [Iacobus Publicius], Ars memorativa, [Cologne: Johann Guldenschaff, around 1481], [7v-8r]. Bodleian Library, Bod-inc., P-535.
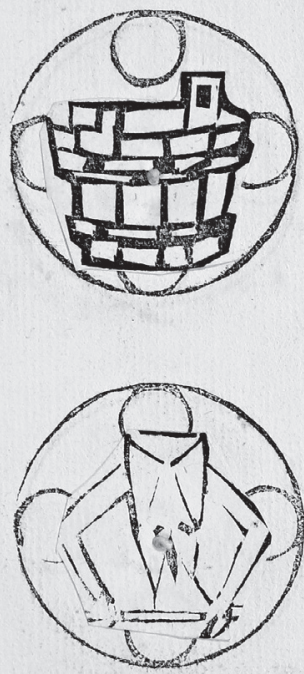

Fig. 7: Mnemonic alphabet, letters $\mathrm{D}^{2}$ and $\mathrm{E}^{2}$. [Iacobus Publicius], Ars memorativa, [Cologne: Johann Guldenschaff, around 1481], [3r]. Bodleian Library, Bod-inc., P-535. (and in V90)

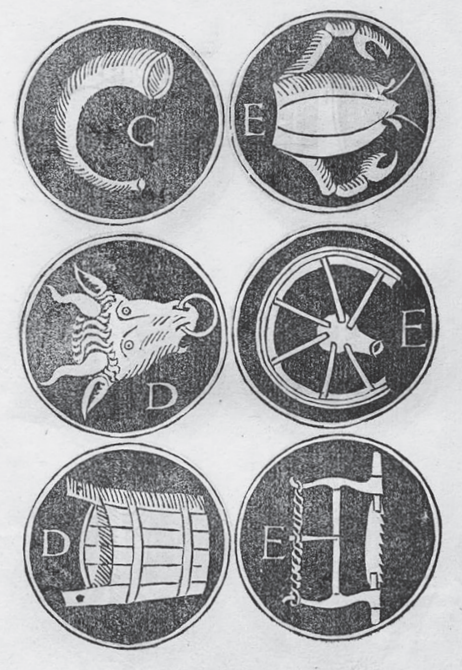

Fig. 8: Mnemonic alphabet, letters $C^{1}$, $\mathrm{D}^{2}$ and $\mathrm{E}^{2}$. Iacobus Publicius, Ars memorativa, Venice: Erhard Ratdolt, 1482, c8r. Bayerische Staatsbibliothek, Ink P-868

As far as the engravings are concerned, there are few differences between V85 and V82. In V85 four new engravings were added and only one removed. This replacement implies the deletion of the last circle in the series of letters, more specifically the circle with the landscape. ${ }^{62}$ In its stead, a different landscape was inserted in the chapter loco-

62 This mnemonic alphabet of sorts became very popular and it was reproduced, among others, by Romberch (1520: E6v-F1v), Leporeus (1523: 19r) and Valadés (1579: 100). 


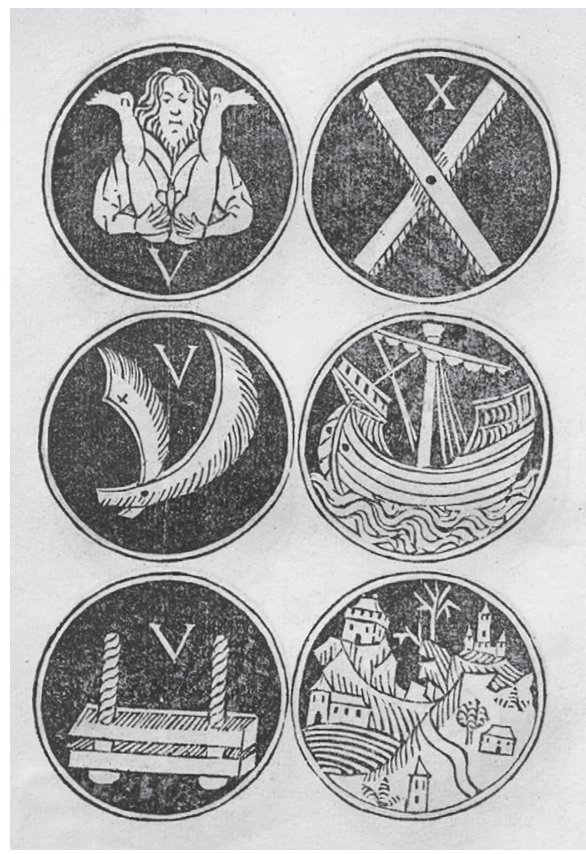

Fig. 9: Mnemonic landscape. Iacobus Publicius, Ars memorativa, Venice: Erhard Ratdolt, 1482, d2v. Bayerische Staatsbibliothek, Ink P-868. nunt cognita dura \& memoratu difficiliora erunt. Locorũ lex preceptione inuentione qualitate difimimilitudine numero no tatione impreffione cömenticiifog locis plene pfecteq; conftat De quibspricipio a ṕceptióe ducto i bocprimo libro dicemus

Pręceptio eft recta agendi ratio: qua nature cổmoda côfirma ta $8<$ igcnii bona adaucta longe latec; dilucefount bic ut ne gd temere adiiciam?. neu gd $\mathrm{p}$ incuriä obmittam? feruandũ eft. Qช effugere qui uolet buig artis obferuantiffimus $\&<$ ṕceptorú cu/

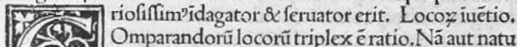
13. Omparandorũ locorũ triplex é ratio. Ná aut natu

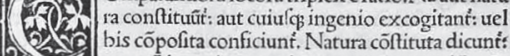
2. - 2 quę nố ingenio excogitata: nec cómentatiōe nüa

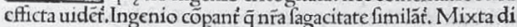

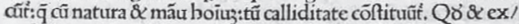
pediés $\&$ côdurcibile magis atł magis effe arbitramur. Oia eni a natura cốftituta repire ê ipoffibile $₫<$ fictis oibus uti durü $\delta$ Cocorü qualitas.

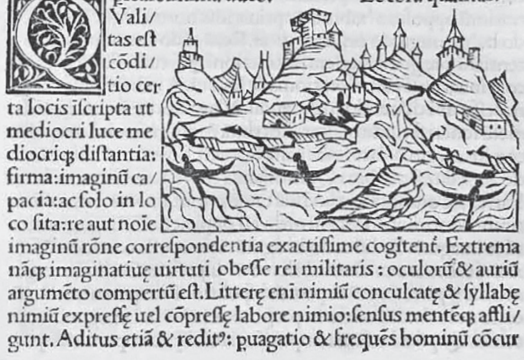

Fig. 10: Mnemonic landscape. Iacobus Publicius, Ars memorativa, Venice: Erhard Ratdolt, 1485, G5v. Herzog August Bibliothek Wolfenbüttel, A: 79 Quod. (6).

rum qualitas (Fig. 9 and 10). In addition to the similarities between both engravings, its relocation within the text seems especially relevant, since the engraving apparently illustrates the concepts on locorum inventio, the chapter following immediately after this one, where the author argues that out of the three mechanisms to come up with mnemonic places (natura, ingenium, and a combination of the two), the combination of natural and artificial elements is the most advisable method. This is indeed what can be observed in the new landscape, where we find the sea, the countryside, the hills (natural elements) dotted with boats, houses, and watchtowers (artificial elements).

The engraving of the cosmos that illustrates the chapter de locis comenticiis, whose authorship Carruthers and Bayerle rightly attribute to Ratdolt, ${ }^{63}$ does not seem as consistent with the content of Ars memorativa. However, we believe this is not the case of the two new engravings. The first one depicts the figures of a man and a woman, practically naked and with outstretched arms.

This would probably imply that Publicius was trying to illustrate the mechanism whereby mnemonic words can be created by attaching letters to different parts of the human body. The mechanism is scarcely illuminated, which makes it obscure. However, in any case, the figures are not alien to the contents of the text. ${ }^{64}$ Finally, this edition

63 Carruthers, Bayerle (2002: 229).

64 Unica littera plures referre perpulchrum est, ut quodcumque $\Delta$ perfossa ea parte corporis locetur, nomen verbumque variat, ut in hac figura patebit $(\mathrm{H} 2 \mathrm{r})$. There is also an image of a naked man in $\mathrm{Z}$, but without a caption (Fig. 6). As Kiss (2008: 115) rightly notes, the lack of captions makes the interpre- 
(V85) includes a two-page tree almost at the end of the work, between the chessboard and the animal grid diagram. This arbor memoriae is relevant to the text. In fact, it is referred to as tabula dupliciter depicta from the earliest editions of the text, although it is only to be found now. 65

Therefore, as far as the engravings are concerned, there are noticeable differences between the two Venice editions by Ratdolt (V82 and V85). But the differences are even more striking if we look at the text itself. In this regard, it should be noted first that $\mathrm{Pu}$ blicius corrects several passages of the earlier edition. These changes are negligible for the most part, and they do not affect the substance of the ideas in the text. The only chapter where significant changes may be observed belongs to the second book (V82), here called Memorie per adiunctionem literarum alleviatio (V85). Here, Publicius describes the instructions to operate what Carruthers and Bayerle call "The Wheel for Combining Letters". ${ }^{66}$ In order to make this combination mechanism more easily understandable, Publicius relocates a statement and adds a new one, but the instructions are not changed in essence. In fact, both versions use the same engraving. ${ }^{67}$

Truth be told, the comparative analysis of the two Venice editions brings to light that the most significant change does not affect directly the content of the work itself but the way of the text, that is, its structure. According to Carruthers and Bayerle, the addition of a new chapter, the third one, is the only modification. This new chapter deals with the training and strengthening of memory through medicinal remedies. ${ }^{68}$ However, a close scrutiny of both versions reveals that there is actually no new chapter. What happens is that some chapters have been renamed and, especially, that some materials have been rearranged in different chapters and books. This is of particular relevance in the case of the original first book, whose contents are now to be found in books one and three of the later version. These modifications have been summarized, for ease of reference, in the following diagram (Fig. 11), where we can see that the first book has been "ransacked" of contents that are now found in the third book (formerly, the second book). Thus, these are not novel contents; they have simply been relocated within the treatise. In the following graph below (Fig. 12), it can be clearly seen how the first book gets completely emptied for the benefit of the third book. Therefore, the main innovation of V85 regard-

tations in the manuscripts all the more interesting. Along the same lines, British Library Ms. Add 28805 - a copy of V85, according to Carruthers, Bayerle (2002: 226) - depicts the figure of a man with inscriptions in different parts of his body. The woman, however, has no inscriptions. This would suggest that its owner was trying to apply Publicius's method. According to Doležalová, Kiss (2014: 134), the absence of captions or annotations is due to the fact that "chaque enseignant de lart de la mémoire désirait gagner sa vie, raison pour laquelle il aspirait à se rendre indispensable. Ces traités sont donc rédigés de sorte qu'ils restent presque incompréhensibles sans explication du professeur".

65 Carruthers, Bayerle (2002: 230): "This latter image, which does not appear in the first incunable edition, played an important role in Raymond Llull's classification of universal knowledge." However, this tabula dupliciter depicta is mentioned in all editions and it is even possible that from the extant copies of the first editions ( $M$ and $G$ ) this and other engravings may have been lost, as suggested by the fact that $Z$ does have them (figs. 1-4).

66 Carruthers, Bayerle (2002: 227).

67 This is the statement that was relocated at the beginning of the chapter: Caput namque rei cuiusque obliqua linea circunductum variabimus figura quadrati. A new statement is inserted towards the end of the chapter: Que versibus his cernuntur complexa: Prima tenet centrum $O$, celum medium diem $D$, septem F triones, omni recurta $\mathrm{O}$ sibi sit rotunda $(\mathrm{H} 4 \mathrm{r})$. Here, the reference to Hebrew letters is present again, after having been removed from the previous version (V82, [c7r]).

68 Carruthers, Bayerle (2002: 226). 


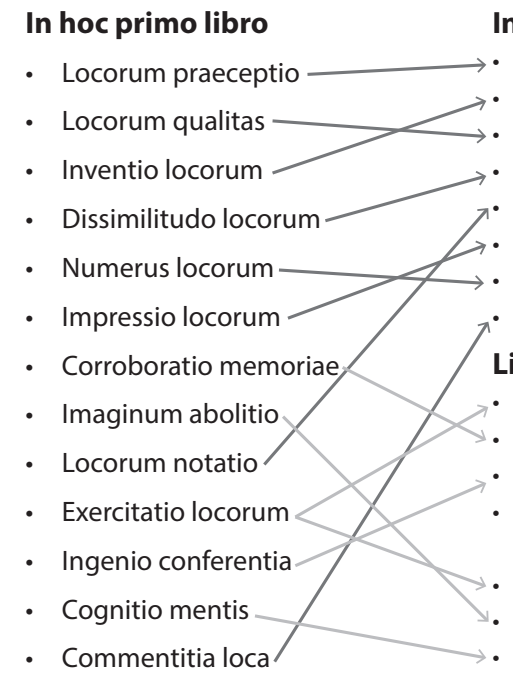

1482
In hoc primo libro

[Praeceptio locorum]

Locorum inventio

Locorum qualitas

Dissimilitudo locorum

Locorum notatio

Impressio locorum

Locorum multitudo

Commentitia sive ficta loca

Liber tertius et ultimus

[Exercitatio locorum]

Corroboratio memoriae

Ingenio conferentia

Memoriae per adiunctione litterarum alleviatio

Modus commendandi memoriae ...

Imaginum abolitio

Imaginum repetitio

1485

Fig. 11: New chapter ordering, from V82 to V85.

Ars memorativa Publicii

1482 / 1485

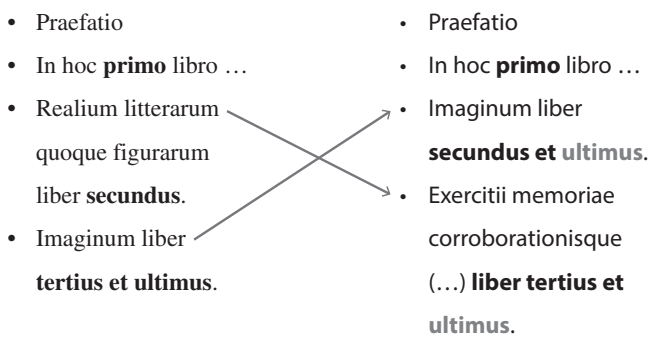

Fig. 12: General structure, from V82 to V85.

ing V82 is not the addition or the removal of new contents but the reorganization of pre-existing contents.

The outcome of all these changes is a well-balanced text, both formally and conceptually. The new version tries to give each of the three books equal weight, and also to make their respective contents more homogeneous. The first book, clearly oversized in the first editions $(\mathrm{M}, \mathrm{G})$, is now strictly reduced to the analysis of loci. Imagines are now the domain of the second book, which remains practically intact from the earlier version except for its new position within the whole - it used to be the third (and last) book. Oddly enough, the editor did not realize that it was no longer the last book, and so the 1485 version has two "last" books: the second and the third one.

The third and final book incorporates into the scarce contents it had in the earlier version the discussion on memory exercitatio and the physiological maintenance of its natural qual- 
ities; i.e., the chapter on medicinal matters that was formerly part of the first book under the title ingenio conferentia. The immediate consequence of this rearrangement of materials is a book that is better organized and with a more conventional layout - its compositional structure adhering to the classical order: loci, imagines, exercitatio and medicinal advice.

\section{Conclusion}

Three stages can therefore be distinguished in the history of the printed text of Ars memorativa. The first of these comprises two volumes ( $\mathrm{M}$ and $\mathrm{G}$ ), published in different years and cities (Toulouse and Paris, around 1477). Curiously enough, the same stage in the composition of the text is also to be found in a later edition ( $Z$, around 1489), which also includes a series of engravings that were probably also part of the first editions, although they were unfortunately lost, at least in M and G. Two versions have been preserved of the second stage of the text: the version that seems be earlier (Bod, NY, around 1481) has no tituli and even omits the name of the author. It has some engravings, all of them with moving parts, depicting a combination of imagines and literae reales. The mnemonic alphabet matches for the most part that of the first Venice edition by Ratdolt (V82), which also includes a few other carefully crafted illustrations. At any rate, with regards to the earlier version, the second stage of the text of Ars memorativa is enriched by virtue of two significant additions: the chapters divisio memorie and de ordine. These two chapters, both inserted at the beginning of the treatise, allow the reconciliation of the neo-Platonic conception of natural memory with the methods and rules of artificial memory with a clear wink to the Rhetorica ad Herennium and neo-Aristotelian philosophy. ${ }^{69}$ Because of Ratdolt's work, Ars memorativa was linked in 1482 to two rhetorical treatises (Institutiones oratoriae and Ars epistolandi), and the resulting volume was published under the generic title Oratoriae artis epitomata. Among the engravings in this version (V82) we find one describing a mechanism to create mnemonic words through the combination of vowels and consonants. This mechanism had been outlined in a way in the earliest versions and, because of its complexity, its formulation would undergo certain changes in the third (and last) version of the text, printed by Ratdolt in 1485 (V85).

With regards to the previous version, the second one is characterized by a profound rearrangement of the contents across all the books of the text. A large part of the chapters, initially in the first book, passes now into to the third book. The result of these changes is a more well-balanced text from both the formal and doctrinal point of view. The last version (V85) wants to achieve two aims: put the three books on the same level despite

${ }^{69}$ In the second stage of the text (NY/Bod, V82), Publicius added the chapter divisio memorie which integrates the classical distinction between natural and artificial memory, but in terms more and more close to those of the classical rhetoric. Memory, says Publicius, is like "a roll of writing, a sheet of paper, or a book", while reminiscence is like "a sound, an utterance, or a voice" (Easque tamen invicem distare animadvertunt ut opera volumini, papiro et libro alteram, alteram sono, pronunciationi et voci compararunt, V82, c2r). A similar comparison to that was made by Cicero who, in a Platonic way, likes describing the functioning of the artificial memory as a luck of writing on wax boards (Cic. De orat. II, 354 and II, 360; Cic. Part. 26). See Merino Jerez (2015). But when identifying later the memoria with actus and the reminiscentia with habitus, a kind of Thomist twist is introduced in the doctrine of Publicius. On this matter Merino Jerez (in press). 
having been clearly in favour of the first one before, and homogenize the content of each one of the three books.

The first book, which was oversized with heterogeneous contents in the first versions (M, G, Z; NY/Bod, V82), is now limited to the strict analysis of the loci. The second book is focused on the analysis of the images. And the third and last book includes everything concerned with the exercitatio of the memory and with the physiological care of its natural features, that is, the medicinal chapter which was previously in the first book with the title of ingenio conferentia. As a consequence of these massive reallocations, this manual turns out to be much more well-organized and more traditional since its compositional structure articulated through a simple composite procedure is adjusted to the classical order of loci, imagines, exercitatio and medicinal advice.

Also, new engravings were added - most of which are connected to the doctrine of the text. This seems to indicate that, as Carruthers claims, more often than not these engravings were made by the editor and not the author. In any case, the final result is a well-balanced text in terms of content that is made all the more appealing by the editorial challenge it poses. These two factors surely account for much of its success. To sum up, the final result is a well-balanced work from a doctrinal point of view and an interesting one from the editorial, which both surely explain much of its success.

\section{REFERENCES}

\section{Editions of Iacobus Publicius's Ars memorativa}

Bod = [Iacobus Publicius], Ars memorativa. [Cologne: Johann Guldenschaff, around 1481]. GW M36437. Bodleian Library, Bod-inc., P-535.

$\mathrm{G}=$ Iacobi Publicii in arte memorie. [Paris: Petrus Caesaris and Johannes Stol, around 1475-1480]. GW M36442. Bibliothèque Municipale de Grenoble, I.320[3] Rés.

$\mathrm{M}=$ Iacobi Publitii in arte memorie. [Toulouse: Henric Turner, around 1476]. GW M36443. Bibliothèque Mazarine de Paris, Inc 618-5.

NY = [Iacobus Publicius], Ars memorativa. [Cologne: Johann Guldenschaff, around 1481]. GW M36437.

The New York Public Library, SASB, Rare Book Collection Rm 328 ( $\left.{ }^{\star} \mathrm{KB} 1483\right)$.

$\mathrm{SB}=$ [Iacobus Publicius], Ars memorativa. [Cologne: Johann Guldenschaff, around 1481]. GW M36437. Staatsbibliothek zu Berlin, Inc 899.7.

V82 = Oratoriae artis epitomata [...] Insuper et perquam facilis memorie artis modus Iacobi Publicii Florentini lucubratione in lucem editus. Venice: Erhard Ratdolt, 1482. GW M36431. Bayerische Staatsbibliothek, Ink P-868.

V85 = Oratoriae artis epitoma [...] Insuper et perquam facilis memorie artis modus Iacobi Publicii Florentini lucubratione in lucem editus. Venice: Erhard Ratdolt, 1485. GW M36435. Herzog August Bibliothek Wolfenbüttel, A: 79 Quod. (6).

V90 = Oratoriae artis epitoma [...] Insuper et perquam facilis memorie artis modus Iacobi Publicii Florentini lucubratione in lucem editus. Augsburg: Erhard Ratdolt, 1490. GW M36428. Biblioteca de la Universidad de Salamanca, BG/I. 290(1).

$\mathrm{Z}=$ Iacobus Publicius, Ars memorativa. [Lyon: Jean du Pré, around 1489]. GW 03207. Biblioteca Universitaria de Zaragoza, Fondo Antiguo I 163-4.

Other primary and secondary sources

Bayerle, H., 2002. 'Jacobus Publicius, The Art of Memory'. Transl. by H. Bayerle. In: Carruthers, Ziolkowski (2002: 231-254). 
Carruthers, M., Bayerle, H., 2002. [Introduction of Jacobus Publicius, The Art of Memory]. In: Carruthers, Ziolkowski (2002: 226-231).

Carruthers, M., Ziolkowski, J. M. (eds.), 2002. The Medieval Craft of Memory. An Anthology of Texts and Pictures. Philadelphia: University of Pennsylvania Press.

Denis, M., 1789. Annalium typographicorum Michaelis Maittaire supplementum. Pars II. Vienna: Kurzbek.

Doležalová, L., Kiss, F. G., 2014. 'Le pouvoir des mots dans l'art de la mémoire à la fin du Moyen Âge'. In: N. Bériou, J.-P. Boudet, I. Rosier-Catach (eds.), Le pouvoir des mots au Moyen Âge. Turnhout: Brepols, 127-154.

GW = Gesamtkatalog der Wiegendrucke. https://www.gesamtkatalogderwiegendrucke.de/ [accessed July $24,2020]$.

Heimann-Seelbach, S., 2000. Ars und Scientia. Genese, Überlieferung und Funktionen der mnemotechnischen Traktatliteratur im 15. Jahrhundert. Tübingen: Niemeyer.

Hillard, D., 1989. Catalogues régionaux des incunables des Bibliothèques publiques de France. Volume VI. Bibliothèque Mazarine. Bordeaux: Societé des bibliophiles de Guyenne / Paris: Aux amateurs de livres.

Kemper, A., 2018. 'Jacobus Publicius und sein Schüler. Die Gedächtniskunst als akademische Übung im Erfurter Universitätsunterricht'. Ars \& Humanitas 12/2, 271-284.

Kemper, A., 2019. 'Jacobus Publicius (Incipit: Haud ab re fore arbitror)'. In: S. Seelbach, A. Kemper (eds.), Zentrale Gedächtnislehren des Spätmittelalters. Eine Auswahl von Traktaten mit Übersetzung und Kommentar. Berlin: Walter de Gruyter, 333-395.

Kiss, F. G., 2008. 'Valentinus de Monteviridi (Grünberg) and the Art of Memory of Conrad Celtis'. In: R. Wójcik (ed.), Culture of Memory in East Central Europe in the Late Middle Ages and the Early Modern Period. Conference proceedings, Ciążeń, March 12-14, 2008. Poznań: Biblioteka Uniwersytecka, 105-118.

Leporeus, G., 1523. Ars memorativa. Toulouse: Gabriel Turnoer.

Maignien, E., 1899. Catalogue des incunables de la Bibliothèque municipale de Grenoble. Mâcon: Protat frères.

Merino Jerez, L., 2015. 'Notatae similitudines / notae similitudines: de la Rhetorica ad Herennium al Ars memorativa'. Revista de Estudios Latinos 15, 97-111.

Merino Jerez, L., in press. 'Towards a typological classification of Iacobus Publicius's Ars memorativa'.

Morcillo Romero, J. J., 2015. El Ars memorativa de G. Leporeo (estudio, edición, crítica, traducción, notas e indices). Tesis doctoral. Universidad de Extremadura.

Redgrave, G. R., 1894. Erhard Ratdolt and his Work at Venice. London: Chiswick Press.

Romberch, I., 1520. Congestiorum artificiosae memoriae. Venice: Georgius de Rusconibus.

Rossi, P., 2000. Logic and the Art of Memory. The Quest for a Universal Language. London / New York: Continuum (reprint 2006).

Sottili, A., 1975. 'Note biografiche sui petrarchisti Giacomo Publicio e Guinoforte Barzizza e sull'umanista valenziano Giovanni Serra'. In: F. Schalk (ed.), Petrarca 1304-1373. Beiträge zu Werk und Wirkung. Frankfurt am Main: Vittorio Klostermann, 270-286.

Sottili, A., 1985. Giacomo Publicio, 'Hispanus', e la diffusione dell'Umanesimo in Germania. Premessa di Francisco Rico. Barcelona: Universidad Autónoma de Barcelona.

Thayer, A. T., 2016. 'Selections in a World of Multiple Options: The Witness of Thomas Swalwell, OSB'. In: B. Roest, J. Uphoff (eds.), Religious Orders and Religious Identity Formation, ca. 1420-1620. Discourses and Strategies of Observance and Pastoral Engagement. Leiden / Boston: Brill, 110-124.

Valadés, D., 1579. Rhetorica Christiana. Perugia: Petrus Iacobus Petrutius.

Volkmann, L., 1929. 'Ars memorativa' Jahrbuch der Kunsthistorischen Sammlungen im Wien: Neue Folge 3, 111-203.

Wójcik, R., 2012. 'Masters, Pupils, Friends, and Thieves. A Fashion of Ars Memorativa in the Environment of the Early German Humanists'. Daphnis 41, 399-418.

Wójcik, R., 2016. 'The Art of Memory in Poland in the Late Middle Ages (1400-1530)'. In: F. G. Kiss (ed.), The Art of Memory in Late Medieval Central Europe (Czech Lands, Hungary, Poland). Budapest / Paris: L'Harmattan, 65-108.

Yates, F. A., 1966. The Art of Memory. London: Routledge / Kegan Paul. 


\section{ARS MEMORATIVA IACOBA PUBLICIA. NÁSTIN VÝVOJE (TIŠTĚNÉHO) TEXTU}

Ve vývoji tištěného textu Ars memorativa Iacoba Publicia lze rozlišit tři stadia. První z nich zahrnují dva svazky publikované v Toulouse a Paříži kolem roku 1477 a totéž stadium kompozice textu figuruje i v jedné pozdější edici (vydané kolem roku 1489). Druhé stadium je dochováno ve dvou verzích. Ta zřejmě dřivější (kolem roku 1481) postrádá tituli, a dokonce v ní není uvedeno ani jméno autora. Obsahuje ale různé rytiny s pohyblivými komponenty, které představují kombinaci imagines a literae reales. Druhá verze tohoto druhého stadia byla publikována Ratdoltovou tiskárnou v Benátkách v roce 1482. Ars memorativa byla sdružena se dvěma rétorickými spisy (Institutiones oratoriae a Ars epistolandi) a výsledný svazek byl publikován pod souhrnným titulem Oratoriae artis epitomata. Tato verze obsahuje mnemonickou abecedu, která se velmi podobá té, kterou prezentovala verze z roku 1481, ačkoli nyní jsou téměř všechny obrázky zafixovány. Pokud jde o text, hlavní novinkou je důkladné přeuspořádání obsahu v rámci všech knih. Poslední stadium (1485, u Ratdolta) usiluje o dva cíle: vyrovnat rozdíly mezi jednotlivými knihami, protože dříve byla ta první předimenzována, a homogenizovat obsah každé z těchto tří knih. Výsledkem je práce vyvážená z hlediska didaktického i atraktivní z hlediska editorského. Nepochybně jedno i druhé z velké části vysvětluje její úspěch.

\section{Luis Merino Jerez}

Universidad de Extremadura, Cáceres

lmerino@unex.es 